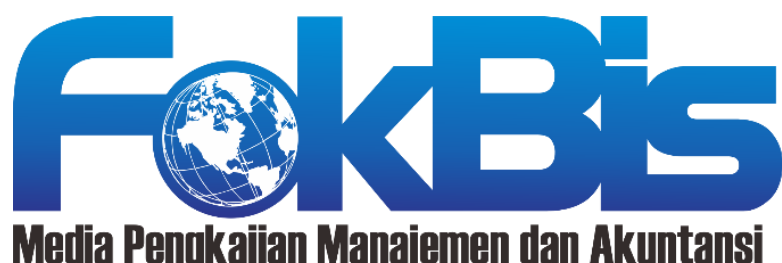

http://journal.stieputrabangsa.ac.id/index.php/fokbis/index

ISSN: 2623-2480/ P-ISSN: 1693-5209

\section{Pengaruh Pendidikan Keuangan Keluarga, Pembelajaran Keuangan di Perguruan Tinggi, Sikap Keuangan dan Teman Sebaya Terhadap Literasi Keuangan Mahasiswa}

\author{
Akhmad Darmawan ${ }^{1}$, Firda Ardianti Pratiwi ${ }^{2}$ \\ 1,2) Fakultas Ekonomi dan Bisnis Universitas Muhammadiyah Purwokerto \\ email: akhmaddarmawan@ump.ac.id
}

Article Information

\author{
History of Article: \\ Received: March 27th 2020 \\ Accepted: July $16^{\text {th }} 2020$ \\ Published: July $31^{\text {st }} 2020$
}

\section{DOI:}

10.32639/fokusbisnis.v19i1.499

\begin{abstract}
ABSTRAK
Tujuan penelitian ini adalah menganalisis pengaruh pendidikan keuangan keluarga, pembelajaran keuangan di perguruan tinggi, sikap keuangan dan teman sebaya terhadap literasi keuangan mahasiswa. Sampel penelitian ini adalah mahasiswa aktif manajemen dan akuntansi S1, di tiga perguruan tinggi terbesar Kota Purwokerto, sampel ini berjumlah 93 mahasiswa aktif dengan pengambilan sampel menggunakan teknik purposive sampling. Data penelitian bersumber dari kuesioner kepada responden dengan data ordinal dan metode analisis yang digunakan adalah analisis regresi linier berganda. Hasil analisa menunjukkan pendidikan keuangan keluarga berpengaruh positif signifikan terhadap literasi keuangan, pembelajaran keuangan di perguruan tinggi berperngaruh positif signifikan terhadap literasi keuangan, sikap keuangan tidak berpengaruh terhadap literasi keuangan dan teman sebaya berpengaruh negatif tidak signifikan terhadap literasi keuangan.
\end{abstract}

Kata kunci: Pendidikan Keuangan, Sikap Keuangan, Litersi Keuangan

\begin{abstract}
The purpose of this study was to analyze the influence of family financial education, financial learning in higher education, financial attitudes and peers on student financial literacy. The sample of this study was active management and accounting students in the three largest colleges of the City of Purwokerto, this sample numbered 93 active students by taking a sample using purposive sampling technique. The research data were sourced from questionnaires to respondents with ordinal data and the analytical method used was multiple linear regression analysis. The analysis showed that family financial education had a significant positive effect on financial literacy, financial learning in higher education had a significant positive effect on financial literacy, financial attitudes had no effect on financial literacy and peers had a non-significant negative effect on financial literacy.
\end{abstract}

Keywords: Financial Education, Financial Attitude, Peers, Financial Literacy 


\section{PENDAHULUAN}

Saat ini sistem keuangan serta inovasi keuangan yang menciptakan kompleksitas produk dan layanan keuangan, diperlukan generasi yang memiliki pemahaman, keterampilan dan keyakinan dalam menggunakan produk dan layanan jasa keuangan. Hal ini penting karena bukti empiris menunjukkan bahwa hal tersebut merupakan salah satu kunci pertumbuhan ekonomi dan stabilitas sistem keuangan di masa depan.

Berdasarkan hasil Survei Nasional Literasi dan Inklusi Keuangan (SNLIK) 2016 yang dilakukan OJK indeks literasi keuangan masyarakat Indonesia mengalami peningkatan dari 21,8\% di tahun 2013 menjadi 29,7\% di tahun 2016 (SNLKI revisit 2017; 17), dan pada tahun 2019 menunjukkan indeks literasi keuangan mencapai 38,03\% dan indeks inklusi keuangan 76,19\% (www.ojk.go.id, 2019).

Sementara itu hasil indeks literasi keuangan OJK 2016 menunjukkan bahwa kalangan pelajar dan mahasiswa, dengan tingkat inklusi keuangan sebesar $64,2 \%$, tingkat literasi keuangan golongan ini masih terbilang sangat rendah yakni sebesar 23,4\%. (SNLIK, 2016). Hal ini sesuai dengan penelitian Margaretha dan Pambhudi (2015) yang menunjukkan bahwa pengetahuan tentang literasi keuangan mahasiswa masih sangat rendah. Menurut Hidajat (2015; 19-20) literasi keuangan yang rendah di kalangan pelajar atau mahasiswa merupakan masalah yang serius karena pelajar atau mahasiswa yang pada saat nya akan menjadi anggota masyarakat dan pada akhirnya akan membuat literasi keuangan masyarakat juga menjadi rendah.

Salah satu kecerdasan yang harus dimiliki oleh manusia modern adalah kecerdasan finansial yaitu kecerdasan mengelola aset keuangan pribadi, sehingga tidak terjebak ke dalam pola hidup konsumtif yang tidak sesuai dengan kemampuan pendapatan dan kondisi keuangan yang bisa berakibat fatal. Untuk memahami pengelolaan keuangan yang baik, dibutuhkan nya pengetahuan pengelolaan keuangan yang cukup baik pula.

Literasi keuangan pribadi sangatlah penting dalam mendukung terwujudnya tujuan-tujuan individu. Dengan melakukan pengelolaan terhadap keuangan pribadi, maka tiap individu tahu akan tujuan yang ingin dicapai, dan memanfaatkan pengelolaan sumber daya keuangan secara optimal untuk mencapai tujuan tersebut. Dengan mengoptimalkan pengelolaan keuangan pribadi, maka individu secara bertanggung jawab mampu merencanakan dan mewujudkan masa depannya (Desry et al, 2019).

Mahasiswa merupakan salah satu potensi besar sebagai penggerak perekonomian Indonesia baik dari segi jumlah populasi, karakter, dan tingkat literasi, serta inklusi keuangan (wartaekonomi.co.id, 2019). OJK menjadikan salah satu sasaran kelompok masyarakat dalam Survei Nasional Literasi Keuangan (SNLK) adalah pelajar, sebagai gerbang terdepan kecerdasan bangsa (Akmal dan Saputra, 2016). Mahasiswa memiliki masalah keuangan yang kompleks karena sebagian mahasiswa belum memiliki pendapatan, cadangan dan terbatas untuk digunakan setiap bulannya, seperti keterlambatan uang kiriman dari orangtua dan uang bulanan habis sebelum waktunya. Hal ini disebabkan oleh kebutuhan yang tidak terduga, pengelolaan keuangan pribadi yang salah, gaya hidup serta pola konsumsi yang boros (Wardani dkk, 2017).

Ada beberapa faktor yang mempengaruhi literasi keuangan mahasiswa, seperti pendidikan keuangan keluarga, pembelajaran keuangan di perguruan tinggi, sikap keuangan dan teman sebaya. Faktor pertama adalah pendidikan keuangan keluarga. pendidikan keuangan keluarga yaitu keluarga merupakan tempat yang paling dominan dalam proses sosialisasi anak tentang masalah keuangan (Mimelientesa, 2018). Hasil penelitian Syuliswati (2019); Putri (2018); Sekarwiti dan Armanto (2016); Sari (2015); Romadoni (2015); dan Shalahuddinta dan Susanti (2014) yang menyatakan bahwa pendidikan keuangan keluarga memiliki pengaruh yang positif signifikan terhadap literasi keuangan mahasiswa. Namun pengaruh penelitian yang dilakukan oleh Rizaldi (2019) dan Melmusi (2017) menunjukan hasil 
bahwa pendidikan keuangan di keluarga berpengaruh negatif signifikan dengan literasi keuangan. Adapaun faktor kedua yang berpengaruh terhadap literasi keuangan adalah pembelajaran keuangan di perguruan tinggi. Pembelajaran keuangan di perguruan tinggi didefinisikan sebagai pembelajaran dalam materi keuangan yang terkait dengan pemahaman literasi keuangan mahasiswa (Herawati, 2015). Penelitian mengenai pembelajaran keuangan di perguruan tinggi telah dilakukan oleh beberapa peneliti diantarannya Syuliswati (2019); Susanti (2019); Melmusi (2017); Saraswati (2017); Sari (2015); dan Shalahuddinta dan Susanti (2014) yang menyatakan bahwa pembelajaran keuangan di perguruan tinggi sangat berperan penting dalam proses pembentukan literasi keuangan mahasiswa sehingga berpengaruh positif signifikan terhadap literasi keuangan. Faktor ketiga yang berpengaruh terhadap literasi keuangan adalah sikap keuangan.

Sikap keuangan diartikan sebagai karakteristikan psikologis seseorang yang berkaitan dengan masalah keuangan pribadi. Financial attitude seperti terbuka terhadap informasi, menilai pentingnya mengelola keuangan tidak implusif dalam konsumsi, orientasi masa depan, dan tanggung jawab (Andansari, 2017). Penelitian mengenai sikap uang telah dilakukan oleh beberapa peneliti diantaranya Rahmayanti (2019); Putri (2018); Ameliawati (2018); Andansari (2017); dan Albeerdy (2015) yang menyatakan bahwa berpengaruh positif signifikan terhadap literasi keuangan mahasiswa. Faktor keempat yang berpengaruh terhadap literasi keuangan adalah teman sebaya. Berbeda dengan penelitian yang dilakukan oleh Yuningsih (2017); Isomidinova (2017); Kartawinata dan Mubaraq (2018); bahwa sikap keuangan tidak berpengaruh secara signifikan terhadap literasi keuangan. Faktor keempat yang berpengaruh terhadap literasi keuangan adalah teman sebaya.

Teman sebaya merupakan kelompok anak-anak dengan tingkat kedewasaan yang sama dan menerapkan prinsip-prinsip hidup bersama serta saling memberikan pengaruh kepada anggota kelompok. Remaja saling dihadapkan pada penerimaan atau penolakan teman sebaya didalam pergaulan (Dewi, 2017). Penelitian mengenai teman sebaya telah dilakukan oleh beberapa peneliti diantaranya penelitian Sekarwiti dan Witjaksono (2016); Alekam et al (2018) yang menyatakan bahwa teman sebaya berpengaruh positif dan signifikan terhadap literasi keuangan dan menurut penelitian Sukmawati (2017) teman sebaya berpengaruh positif terhadap literasi keuangan.

Penelitian ini merupakan penelitian pengembangan dari penelitian terdahulu yang dilakukan oleh Melmusi (2017), pada penelitian sebelumnya hanya menggunakan variabel pendidikan keuangan di keluarga dan pembelajaran keuangan di perguruan tinggi, sedangkan pada penelitian saat ini peneliti menambahkan variabel sikap keuangan yang didukung oleh penelitian Andansari (2017) dan variabel teman sebaya yang didukung oleh Sekarwiti dan Witjaksono (2016). Adapun perbedaan penelitian ini dengan penelitian sebelumnya terletak pada variabel independennya.

\section{TINJAUAN PUSTAKA}

\section{Literasi Keuangan}

Susanti (2019) menjelaskan literasi keuangan merupakan kebutuhan dasar yang dibutuhkan seseorang sehingga mereka dapat menghindari masalah keuangan. Menurut Darmawan et al (2018) Literasi keuangan umum adalah literasi keuangan individu tentang pengetahuan keuangan dan aset keuangan yang ada. Financial literacy atau literasi keuangan memainkan peranan penting bagi setiap orang dalam mengelola keuangan personal (Gunardi, 2017).

Organisation for Economic Co-operation and Development (2016) mendefinisikan literasi keuangan sebagai pengetahuan dan pemahaman atas konsep dan risiko keuangan, berikut keterampilan, motivasi, serta keyakinan untuk menerapkan pengetahuan dan pemahaman yang dimilikinya tersebut dalam 
rangka membuat keputusan keuangan yang efektif, meningkatkan kesejahteraan keuangan (financial well being) individu dan masyarakat, dan berpartisipasi dalam bidang ekonomi (SNLKI, 2017; 16).

Literasi keuangan adalah pengetahuan dan kecakapan untuk mengaplikasikan pemahaman tentang konsep dan risiko, keterampilan agar dapat membuat keputusan yang efektif dalam konteks finansial untuk meningkatkan kesejahteraan finansial, baik individu maupun sosial, dan dapat berpartisipasi dalam lingkungan masyarakat (Gerakan Literasi Nasional 2017; 5).

\section{Theory of Planned Behavior}

Ajzen \& Fishben (1991). Berdasarkan teori tindakan terencana menjelaskan bahwa intesitas setiap seseorang untuk berperilaku dapat dijelaskan melalui tiga prediktor yang dapat memengaruhi intesitas tersebut, antara lain: yakni subjective norms, attitude toward the behavior and perceived behavioral control. Menurut nya menerangkan bahwa perilaku seseorang mempertimbangkan untuk melakukan atau tidak melakukan sesuatu, maka berbagai pertimbangan tersebut akan membentuk suatu perilaku. Semakin baik pengetahuan dan kecerdasan yang dimiliki, maka semakin baik pula perilakunya. Dapat disumpulkan bahwa, pemahaman dan pengelolaan literasi keuangan bagi semua kalangan masyarakat di Indonesia adalah sangat penting untuk kesejahteraan masyarakat tersebut dalam hal keuangan

\section{Pendidikan Keuangan Keluarga}

Menurut Sina $(2017 ; 79)$ Pendidikan diibaratkan seperti perjalanan sebuah kapal yang mengarungi lautan kehidupan. Ungkapan sebelumnya, memuat dua arti fundamental. Pertama, pendidikan merupakan hal yang wajib dilakukan (long life education). Kedua, pendidikan dimulai dari dalam keluarga. Pendidikan keuangan yang merupakan salah satu manifestasi dari pendidikan mendapatkan kesesuaian yang tepat. Nalarnya adalah tujuan dari pendidikan keuangan adalah menjadikan manusia yang bertanggung jawab atas kondisi keluarganya. Pendidikan keuangan adalah fondasi penting untuk meningkatkan literasi keuangan dan menginformasikan generasi konsumen, pekerja, dan warga negara berikutnya (Lusardi, 2019).

Menurut finansialku.com (2015) pendidikan keuangan keluarga sangat penting karena adanya siklus pemasukan dan pengeluaran didalam keuangan keluarga, keluarga harus mampu mengelola pendapatan saat ini untuk memenuhi tujuan-tujuan keuangan mereka. Pendidikan keuangan keluarga memungkinkan kita untuk dapat merencanakan dan mempersiapkan keuangan sekarang dan masa depan. Hal ini terjadi sesuai dengan teori belajar sosial dimana seseorang belajar dengan meniru peristiwa yang ada di lingkungan keluarga mereka. Sehingga dalam lingkungan keluarga mahasiswa juga dapat melakukan proses belajar. Menurut Melmusi (2017) menyatakan bahwa keluarga yang telah melakukan pendidikan keuangan keluarga adalah orangtua yang telah mengajarkan nilai uang, menunjukan keteladanan yang baik dalam mengelola uang, mengajarkan dan melatih untuk rajin menabung, membiarkan anak dalam melakukan pembayaran sendiri atas kebutuhan tambahan dan mengelola uang saku, serta memiliki intesitas dalam mengelola keuangan anak.

Dapat disimpulkan bahwa pendidikan keuangan keluarga adalah pendidikan yang diterima pertama kali seseorang untuk memperoleh segala pengetahuan dari orangtua yang berlangsung secara terus-menerus mengenai uang dan proses pengembangan perilaku pengelolaan keuangan.

\section{Pembelajaran Keuangan di Perguruan Tinggi}

Menurut Santrock $(2014 ; 245)$ pembelajaran didefinisikan sebagai pengaruh permanen secara relatif pada perilaku, pengetahuan, dan keterampilan berpikir, yang muncul karena pengalaman. Belajar adalah suatu sistem yang terdiri dari berbagai komponen yang saling berhubungan satu sama lain. Komponen itu termasuk tujuan, bahan, metode dan evaluasi. Keempat komponen pembelajaran harus dipertimbangkan oleh guru dalam memilih dan menentukan media, metode, strategi dan pendekatan yang akan digunakan dalam kegiatan pembelajaran (Susanti, 2019). 
Menurut Sari (2015) pembelajaran keuangan di perguruan tinggi sebagai sarana penting bagi sumbangan pengetahuan literasi mahasiswa. Dalam aktifitasnya, perguruan tinggi memberikan mata kuliah, pelatihan, workshop serta forum diskusi kepada mahasiswa. Hal ini secara langsung dapat mempengaruhi tingkat pengetahuan mahasiswa mengenai literasi keuangan yang mahasiswa dapat. Pembelajaran pada perguruang tinggi mengenai keuangan memberikan impact bagaimana mahasiswa menggunakan dana, mempertimbangkan belanja, serta melakukan keputusan keuangan lainnya.

Hal ini terjadi sesuai dengan teori pembelajaran observasional dimana mahasiswa memperoleh keterampilan, strategi dan keyakinan dengan mengamati orang lain. Selain itu, individu memang diciptakan untuk hidup dalam lingkungan sosial sehingga dalam lingkungan perguruan tinggi, mahasiswa juga dapat melakukan proses belajar.

Pembelajaran di perguruan tinggi didefinisikan sebagai pembelajaran dalam materi keuangan yang terkait dengan pemahaman literasi keuangan mahasiswa (Herawati, 2015). Menurut Melmusi (2017); Wardani (2017); Sari (2015) pembelajaran di perguruan tinggi sangat berperan penting dalam proses pembentukan literasi keuangan mahasiswa. Pembelajaran yang efektif dan efisien akan membantu mahasiswa memiliki kemampuan memahami, menilai, dan bertindak dalam kepentingan keuangan mereka. Sehingga mahasiswa mampu mengimplementasikan dan memahami hasil pembelajaran di perguruan tinggi dengan kehiudpan sehari-hari. Dapat disimpulkan bahwa, pembelajaran keuangan di perguruan tinggi dapat diperoleh berdasarkan tujuan kursus manajemen keuangan dan anggaran perusahaan yang dapat digunakan sebagi indikator bahwa siswa mendapatkan pembelajaran keuangan dalam perguruan tinggi.

\section{Sikap Keuangan}

Sikap uang adalah posisi seseorang dalam kelompok masyarakat yang ditentukan oleh jenis kegiatan ekonomi, pendidikan dan pendapatan (Sukartha et al, 2018). Sikap keuangan sebagai ideologi keuangan individu yang mengarah pada penciptaan dan pemeliharaan nilai-nilai terhadap masalah keuangan (Mahapatra et al, 2016). Sikap keuangan yang bijak diawali dengan adanya tujuan keuangan yang dimiliki seseorang. Tujuan keuangan tersebut merupakan wadah bagaimana seseorang dapat merencanakan dan mengelola keuangan dengan baik dalam jangka pendek maupun panjang (SNLKI, 2017;83).

Menurut Ameliawati (2018) sikap keuangan dapat memiliki implikasi penting dalam literasi keuangan. Seseorang dengan sikap keuangan akan berdampak pada literasi keuangan yang tinggi. Dengan kemampuan keuangan yang baik orang dapat membuat pilihan tentang produk keuangan yang baik pula, untuk masa depan mereka dan uang dapat mempengaruhi seseorang untuk berpikir dan bertindak sesuai dengan sikap orang tersebut. Sikap uang merupakan kecenderungan sikap yang bersifat positif atau negatif terhadap uang. sikap positif terhadap uang akan mempengaruhi seseorang yang akan memiliki pemahaman dan literasi keuangan yang lebih baik, sedangkan sikap negatif akan menyebabkan manajemen, pengetahuan, dan kehancuran keuangan yang buruk (Albreedy, 2017).

Hal ini terjadi sesuai dengan Theory of Planed Behavior menurut Ajzen (1991) dimana pemikiran seseorang tentang uang akan mempengaruhi kemampuannya dalam pengelolaan uang yang berdampak pada munculnya perbedaan persepsi atau suatu objek fisik atau objek perilaku nya yang pada akhirnya membentuk sikap yang berbeda. Dapat disimpulkan bahwa sebagai seorang mahasiswa hendaknya dapat memiliki kemampuan dalam pengelolaan uang yang baik dalam hal mengelola keuangan.

\section{Teman Sebaya}

Teman sebaya dikatakan sebagai hubungan sosial yang terbentuk karena adanya tujuan pencarian jati diri yang dilakukan oleh dua orang atau lebih yang memiliki usia yang setara, serta kematangan yang sama, dimana mereka saling mengenal identitas sosial satu sama lain dan dapat mempengaruhi satu sama lain (Sakinah, 2016). Menurut Yusuf $(2016 ; 95)$ teman sebaya mempunyai peranan penting bagi remaja. 
Remaja sering menempatkan teman sebaya dalam posisi prioritas apabila dibandingkan dengan orang tua atau gurunya.

Menurut Dewi (2017) bahwa teman sebaya merupakan kelompok anak-anak dengan tingkat kedewasaan yang sama dan menerapkan prinsip-prinsip hidup bersama serta saling memberikan pengaruh kepada anggota kelompok. Remaja saling di hadapkan pada penerimaan atau penolakan teman sebaya di dalam pergaulan.

Teori yang berkaitan dengan teman sebaya, salah satunya teori ekologi menurut Urie Brofenbrenner 1917, berdasarkan teori ekologi ini teman sebaya dengan adanya pola pergaulan diantara mereka dapat mempengaruhi literasi keuangan mahasiswa. Temuan pada penelitian ini didukung oleh Sekarwiti dan Witjaksono (2016); Alekam., et al (2018) yang menyatakan bahwa teman sebaya berpengaruh positif dan signifikan terhadap literasi keuangan dan menurut penelitian Sukmawati (2017) teman sebaya berpengaruh positif terhadap literasi keuangan. Dapat disimpulkan bahwa teman sebaya setelah masuk perguruan tinggi, mahasiswa mulai bergaul dengan teman sebayanya dan menjadi anggota dari kelompoknya. Pada saat inilah mereka mulai mengalihkan perhatian nya untuk mengembangkan sifatsifat atau perilaku yang cocok atau dikagumi oleh teman-teman nya, dikarenakan teman sebaya dapat membawa pengaruh yang lebih besar kepada mahasiswa.

\section{METODE PENELITIAN}

Jenis penelitian ini menggunakan jenis penelitian kuantitatif. Populasi dalam penelitian ini adalah para mahasiswa Program Studi Manajemen dan Akuntansi FEB UMP, UNSOED dan UNWIKU Tahun Angkatan 2016. Jumlah mahasiswa Program Studi Manajemen dan Akuntansi FEB UMP, UNSOED dan UNWIKU Tahun Angkatan 2016 mencapai 803 mahasiswa maka penelitian ini dilakukan secara sampling. Sedangkan teknik pengambilan data menggunakan Purposive Sampling adalah teknik penentuan sampel dengan pertimbangan tertentu (Sugiyono, 2015; 218). Sampel yang diambil dalam penelitian ini memiliki kriteria-kriteria tertentu yaitu : (1) Mahasiswa aktif Program Studi Manajemen dan Akuntansi Fakultas Ekonomi dan Bisnis Universitas Muhammadiyah Purwokerto, Universitas Jendral Soedirman Purwokerto dan Universitas Wijaya Kusuma Purwokerto Tahun Angkatan 2016. (2) Mahasiswa yang sedang/telah menempuh matakuliah manajemen keuangan. Penelitian ini menggunakan tingkat kesalahan $10 \%$. Jumlah sampel penelitian ini adalah 93 mahasiswa Program Studi Manajemen dan Akuntansi FEB UMP, UNSOED dan UNWIKU Tahun Angkatan 2016yang telah memenuhi kriteria diatas. Peneliti menggunakan metode pengumpulan data dengan melakukan penyebaran kuesioner secara langsung kepada mahasiswa.

\section{HASIL DAN PEMBAHASAN}

\section{Uji Validitas dan Uji Reliabilitas}

Uji validitas digunakan untuk mengukur sah atau valid tidaknya suatu kuisioner. Suatu kuisioner dikatakan valid jika pertanyaan pada kuisioner mampu mengungkapkan sesuatu yang akan diukur oleh kuisioner tersebut (Ghozali,2016:52). Pada hasil penelitian ini uji signifikan dilakukan dengan membandingkan antara nilai $r$ hitung dengan tabel $r$ untuk degree of freedom $(d f)=n-2=(93-2=91)$ sehingga didapatkan angka sebesar 0,171 dimana hasilnya menunjukkan bahwa semua $r$ hitung $>r$ tabel $(0,171)$ yang menyatakan bahwa semua pernyataan dinyatakan valid. Reliabilitas sebenarnya adalah alat untuk mengukur suatu kuisioner yang merupakan indikator dari variabel atau konstruk. Suatu kuisioner dikatakan reliabel atau handal jika jawaban seseorang terhadap pernyataan adalah konsisten atau stabil 
dari waktu ke waktu. Suatu konstruk atau variabel dikatakan reliabel jika memberikan nilai Cronbach Alpha > 0,60 (Ghozali,2018:254). Berdasarkan hasil penelitian Cronbach Alpha semua variabel yaitu $(0,696 ; 0,783 ; 0,812 ; 0,757 ; 0,734)>0,60$ maka dinyatkan reliabel.

\section{Uji Asumsi Klasik}

a) Uji Normalitas Dalam penelitian ini, uji normalitas akan dilakukan dengan menggunakan analisis kolmogorof-smirnov test (K-S). Uji KS dalam mengambil kesimpulan untuk menentukan normal atau tidak adalah dengan melihat nilai signifikansinya. Jika signifikan $>0,05$ maka variabel berdistribusi normal dan sebaliknya jika signifikan $\leq 0,05$ maka variabel tidak berdistribusi normal (Ghozali, 2016; 154). Berdasarkan hasil penelitian menunjukkan bahwa Asymp.sig. (2-tailed) yaitu 0,200 >0,05 dan data dinyatakan berdistribusi normal.

b) Uji Multikolonieritas Berdasarkan analisis data yang dilakukan diketahui bahwa semua nilai VIF $(1,035 ; 1,043 ; 1,006 ; 1,020) \leq 10$ dan nilai toleransinya $(0,966 ; 0,959 ; 0,994 ; 0,980) \geq 0,10$, maka tidak terjadi multikolonieritas. Dan disimpulkan bahwa uji multikolonieritas terpenuhi.

c) Uji Heteroskedastisitas Berdasarkan hasil uji glejser dapat diketahui bahwa nilai signifikansi dari keempat variabel $(0,361 ; 0,418 ; 0,087 ; 0,955)>0,05$. Dengan demikian dapat disimpulkan bahwa tidak terdapat masalah heteroskedastisitas.

\section{Uji Kecukupan Model Koefisien Determinasi}

Pada penelitian ini menunjukkan bahwa koefisien determinasi yang menunjukkan nilai Adjusted $\mathrm{R}$ square 0,095 atau 9,5\%. hal ini menunjukkan bahwa variabel pendidikan keuangan keluarga, pembelajaran keuangan di perguruan tinggi, sikap keuangan dan teman sebaya mempengaruhi literasi keuangan mahasiswa hanya sebesar 9,5\%, variabel-variabel independen dalam menjelaskan variasi variabel amat terbatas dan sisanya dijelaskan oleh variabel lain diluar model regresi penelitian ini yaitu variabel gaya hidup dan tempat tinggal/residence yang dapat memengaruhi literasi keuangan.

Uji Kecocokan Model (F test) Berdasarkan hasil uji Regresi dapat diketahui nilai F hitung sebesar 3,425 dengan signifikansi 0,012. Sedangkan $\mathrm{F}$ tabel pada tingkat kepercayaan $95 \%$ adalah sebesar 2,48. Dengan demikian $\mathrm{F}$ hitung $>\mathrm{F}$ tabel $(3,425>2,48)$. Berdasarkan hasil uji $\mathrm{F}$ ini berarti pendidikan keuangan keluarga, pembelajaran keuangan di perguruan tinggi, sikap keuangan dan teman sebaya, bahwa persamaan regresi yang terbentuk masuk kriteria kecocokan model (fit) dengan tingkat signifikansi 0,012 karena probabilitas 0,012 jauh lebih kecil dari 0,05.

\section{Uji t Parsial}

Berdasarkan hasil penelitian menunjukkan bahwa:

a) Hasil penelitian hipotesis Pertama diperoleh nilai signifikansi sebesar 0,025 < 0,05 (H1 diterima), dengan $t_{\text {hitung }}>t_{\text {tabel }}$ yaitu 2,282> 1,662 maka secara statistik pendidikan keuangan keluarga berpengaruh positif signifikan terhadap literasi keuangan mahasiswa. Hal ini berarti bahwa pendidikan keuangan keluarga yang diberikan keluarga tinggi maka tingkat literasi keuangan yang dimiliki mahasiswa akan tinggi pula. Sebaliknya, jika semakin buruk pendidikan keuangan keluarga mahasiswa, maka semakin rendah tingkat literasi keuangan mahasiswa. Hal ini sesuai dengan teori belajar sosial oleh Bandura (1977) dan di dukung oleh penelitian terdahulu yang dilakukan Syuliswati (2019); Putri (2018); Sekarwiti dan Witjaksono (2016); Sari (2015); Romadoni (2015); dan Shalahuddinta dan Susanti (2014) yang menyatakan bahwa pendidikan keuangan keluarga memiliki pengaruh yang positif signifikan terhadap literasi keuangan mahasiswa. 
b) Hasil penelitian hipotesis Kedua diperoleh nilai signifikansi sebesar 0,022 < 0,05 (H2 diterima), dengan $t_{\text {hitung }}>t_{\text {tabel }}$ yaitu 2,282 $>1,662$ maka secara statistik pembelajaran keuangan di perguruan tinggi berpengaruh positif signifikan terhadap literasi keuangan mahasiswa. Hal ini berarti bahwa semakin baik proses pembelajaran di perguruan tinggi tentang keuangan dapat meningkatkan literasi keuangan mahasiswa. Sebaliknya, jika semakin buruk pembelajaran keuangan di perguruan tinggi mahasiswa, maka semakin rendah tingkat literasi keuangan mahasiswanya. Hal ini sesuai dengan teori pembelajaran observasional oleh Bandura (1986) dan di dukung oleh penelitian terdahulu yang dilakukan Syuliswati (2019); Susanti (2019); Melmusi (2017); Saraswati (2017); Sari (2015); dan Shalahuddinta dan Susanti (2014) yang menyatakan bahwa pembelajaran keuangan di perguruan tinggi memiliki pengaruh yang positif signifikan terhadap literasi keuangan mahasiswa.

c) Hasil penelitian hipotesis Ketiga diperoleh nilai signifikansi sebesar 0,405 > 0,05 (H3 ditolak), dengan thitung < ttabel yaitu $0,836<1,662$ maka secara statistik sikap keuangan tidak berpengaruh signifikan terhadap literasi keuangan. Hal ini menunjukkan bahwa mahasiswa memiliki sikap keuangan yang buruk maka literasi keuangan nya yang dimiliki rendah. Sebaliknya, jika semakin baik sikap keuangan yang dimiliki mahasiswa, maka semakin tinggi tingkat literasi keuangan mahasiswanya. Bahwa ini sesuai dengan Theory of Planed Behavior Ajzen (1991) dan hasil penelitian ini relevan dengan penelitian sebelumnya yaitu oleh Isomidinova (2017); dan Kartawinata dan Mubaraq (2018) bahwa sikap keuangan tidak berpengaruh signifikan terhadap literasi keuangan.

Hasil penelitian hipotesis Keempat diperoleh nilai signifikansi sebesar 0,194 > 0,05 (H4 ditolak), dengan thitung < ttabel yaitu $-1,308<1,662$ maka secara statistik teman sebaya berpengaruh negatif tidak signifikan terhadap literasi keuangan. Hal ini memberikan pengertian semakin negatif atau rendah pengaruh teman sebaya akan diiringi dengan menurunya tingkat literasi keuangan mahasiswa. Sebaliknya, jika semakin baik pengaruh teman sebaya yang dimiliki mahasiswa, maka semakin tinggi tingkat literasi keuangan mahasiswanya. Terjadinya hubungan yang berpengaruh negatif tidak signifikan, ini didukung oleh teori ekologi Urie Brofenbrenner (1917) akan tetapi hasil penelitian ini tidak relevan dengan penelitian-penelitian sebelumnya, seperti Sekarwiti dan Witjaksono (2016); Alekam et al (2018); dan Sukmawati (2017) yang menyatakan bahwa teman sebaya berpengaruh positif siginifikan terhadap literasi keuangan.

\section{SIMPULAN}

Berdasarkan hasil analisis data dan pembahasan hasil penelitian ini serta hasil pengujian data dan pembahasan yang telah di lakukan maka dapat di ambil suatu kesimpulan: Pendidikan keuangan keluarga berpengaruh positif signifikan terhadap literasi keuangan mahasiswa; Pembelajaran keuangan di perguruan tinggi berpengaruh positif signifikan terhadap literasi keuangan mahasiswa; Sikap keuangan tidak berpengaruh terhadap literasi keuangan mahasiswa; Teman sebaya berpengaruh negatif tidak signifikan terhadap literasi keuangan mahasiswa. 


\section{REFERENSI}

Ajzen, I. (1991). Organizational Behavior and Human Decision Processes. University of Massachusetts at Amherst Research, 1-33.

Akmal, H., \& Saputra, Y. E. K. A. (2016). Analisis tingkat literasi keuangan. Jebi (Jurnal Ekonomi Dan Bisnis Islam), 1(2), 235-244. Retrieved from http://journal.febi.uinib.ac.id/index.php/jebi/article/view/37

Albeerdy, M. I., \& Gharleghi, B. (2015). Determinants of the Financial Literacy among College Students in Malaysia. International Journal of Business Administration, 6(3), 15-24. https://doi.org/10.5430/ijba.v6n3p15

Ameliawati, M., \& Setiyani, R. (2018). The Influence of Financial Attitude, Financial Socialization, and Financial Experience to Financial Management Behavior with Financial Literacy as the Mediation Variable. KnE Social Sciences, 3(10), 811. https://doi.org/10.18502/kss.v3i10.3174

Andansari, P. I. (2018). Pengaruh Financial Attitude Dan Lingkungan Sosial Terhadap Literasi Keuangan Mahasiswa. Ecodunamika: Jurnal Pendidikan Ekonomi, 1(1), 1-7. https://doi.org/https://ejournal.uksw.edu/ecodunamika/article/view/1519

Darmawan, A., Suyoto, Widhiandono, H., Utami, N. H., Razak, A. A. Z. A., \& Ab Wahid, H. (2018). The Effect of Financial Literacy, Financial Experience, and Locus of Control Towards Financial Management Attitude and Family Investment Planning Behavior. 206-215.

Dewanty, N., \& Isbanah, Y. (2018). Determinant of The Financial Literacy: Case Study on Career Woman in Indonesia. Etikonomi, 17(2), 285-296. https://doi.org/10.15408/etk.v17i2.6681

Ghozali, I. (2016). Aplikasi Analisis Multivariete Dengan Program IBM SPSS 23 (8th ed.). Semarang : Badan Penerbit Universitas Diponegoro: badan penerbit universitas diponegoro.

Gunardi, A., Ridwan, M., \& Sudarjah, G. M. (2017). The Use of Financial Literacy for Growing Personal Finance. Jurnal Keuangan Dan Perbankan, 21(3), 446-458. https://doi.org/10.26905/jkdp.v21i3.1489

Hidajat, T. (2016). Literasi Keuangan. Retrieved from https://play.google.com/books/reader?id=UBq8DAAAQBAJ\&hl=in\&printsec=frontcover\&pg=GBS. PA1\%0D

Isomidinova, G., \& Singh, J. S. K. (2017). Determinants of financial literacy : a quantitative study among young students in Tashkent, Uzbekistan. Electronic Journal of Business \& Management, 2(1), 6175 .

Kartawinata B, M. M. (2018). Pengaruh Kompetensi Keuangan Terhadap Literasi Keuangan. Kajian Pendidikan Ekonomi Dan IImu Ekonomi, II, 87-100. https://doi.org/10.1109/tsc.2012.35

Kemendikbud, T. G. (2017). Materi Pendukung Literasi Finansial. In M. H. Dr. Luh Anik Mayani (Ed.), Gerakan Literasi Nasional (pp. 1-41). https://doi.org/http://dikdasmen.kemdikbud.go.id

Lusardi, A. (2019). Financial literacy and the need for financial education: evidence and implications. Swiss Journal of Economics and Statistics, 155(1), 1-8. https://doi.org/10.1186/s41937-019-0027-5 
Mahapatra, M. S., Alok, S., and Raveendran, J. (2016). Financial Literacy of Indian Youth: A study on the Twin cities of Hyderabad-Secunderabed. IIM Kozhikode Society \& Management Review, 6(2), 1-16. https://doi.org/https://doi.org/10.1177/2277975216667096

Margaretha, F., \& Pambudhi, R. A. (2015). Tingkat Literasi Keuangan Pada Mahasiswa S-1. Jmk, 17(1), 7685. https://doi.org/10.9744/jmk.17.1.76

Melmusi, Z. (2017). Faktor Faktor Yang Mempengaruhi Literasi Finansial Mahasiswa Fakultas Ekonomi (Studi Kasus di Universitas Putra Indonesia "YPTK" Padang). Majalah IImiah, 24(2), 221-229.

Natalia, D. E. (2019). Analisis Tingkat Literasi dan Pengelolaan Keuangan Pribadi Mahasiswa di Fakultas Ekonomi dan Bisnis Universitas Sam Ratulangi. Jurnal EMBA, 7(2), 2131-2140.

Pendidikan Keuangan Keluarga Sangat Penting Karena Pendidikan Keuangan Keluarga. (2015). In Finansialku. Retrieved from https://www.finansialku.com/pendidikan-keuangan-keluarga-sangatpenting-karena/\%OD

Putri, A. R., \& Asrori. (2018). Determinan Literasi Finansial Dengan Gendersebagai Variabel Moderasi. Electronic Journal of Business \& Management, 23(1), 61-75. https://doi.org/10.18502/kss.v3i10.3174

Prasongko, D. (2019). Kejar Target Literasi Keuangan 75 Persen, OJK Gelar Aksimuda (K. Setiawan, ed.). Retrieved from https://bisnis.tempo.co/read/1230135/kejar-target-literasi-keuangan-75-persenojk-gelar-aksimuda

Rahmayanti, W. (2019). Pengaruh Sikap Keuangan dan Perilaku Keuanagn Terhadap Literasi Keuangan (Studi Kasus pada Ibu Rumah Tangga Di Desa Lito Kecamatan Moyo Hulu ). Jurnal Manajemen Dan Bisnis, 2(1), 9. Retrieved from http://jurnal.uts.ac.id

Rahyubi, H. (2014). Teori-Teori Belajar dan Aplikasi Pembelajaran Motorik Deskripsi dan Tinjauan Kritis. Majalengka: Referens dan Nusa Media.

Rizaldi, M. H. (2019). Pengaruh Demografi, Pengalaman Bekerja, dan Pendidikan Pengelolaan Keuangan Orangtua Terhadap Literasi Keuangan Mahasiswa di Perguruan Tinggi Surabaya. Jurnal IImu Manajemen, 7(2), 291-298.

Sakinah, G., \& Mudakir, B. (2018). Analisis Literasi Keuangan Mahasiswa S-1 Fakultas Ekonomika Dan Bisnis Universitas Diponegoro Angkatan 2014 - 2017. Jurnal Dinamika Ekonomi Pembangunan, 1(2), 17. https://doi.org/10.14710/jdep.1.2.54-70

Santrock, J. W. (2014). Psikologi Pendidikan (5th ed.; D. Mandasari, ed.). Jakarta: Salemba Humanika.

Saraswati, E., Rispantyo, \& Kristianto, D. (2017). Pengaruh Proses Pembelajaran Di Perguruan Tinggi Terhadap Perilaku Keuangan Dengan Literasi Keuangan Sebagai Variabel Intervening. Jurnal Akuntansi DanSistem Teknologi Informasi, 13(2), 218-229.

Sari, D. A. (2015). Financial Literacy dan perilaku keuangan mahasiswa. Buletin Bisnis \& Manajemen, 01(02), 171-189. Retrieved from http://journal.stie-yppi.ac.id/index.php/BBM/article/view/14/14

Segara, T. (2016). Survei Nasional Literasi dan Inklusi Keuangan 2016. Jakarta: Departemen Literasi dan Inklusi Keuangan Bidang Edukasi dan Perlindungan Konsumen. 
Sekarwiti, Florentina Krisanti \& Witjaksono, A. (2016). Analisis Pengaruuh Pendidikan Keuangan Keluarga, Tempat Tinggal/Residence, dan Interaksi Teman Sebaya Terhadap Financial Literacy. Jurnal GICI, 6(1), 99-115. https://doi.org/10.1017/СBO9781107415324.004

Sina, G. P. (2016). Financial Contemplation seri1 (Guepedia, ed.). Retrieved from https://play.google.com/books/reader?id=0zrcDQAAQBAJ\&pg=GBS.PP1

Sukmawati, dian. (2016). Pengaruh Prestasi Belajar, Dukungan Sosial Keluarga dan Teman Sebaya Terhadap Literasi Keuangan Siswa. Jurnal Ekonomi Pedididkan Dan Kewirausahaan, 4(1), 30-41. https://doi.org/10.26740/jepk.v4n1.p30-41

Sugiyono. (2015). Metode Penelitian Kuantitatif, Kualitatif, dan R\&D (22nd ed.). Bandung: Alfabeta.

Suliyanto. (2011). Ekonometrika Terapan: Teori \& Aplikasi dengan SPSS (1st ed.; F. S. Suyantoro, ed.). Yogyakarta: ANDI.

Suliyanto. (2018). Metode Penelitian Bisnis Untuk Skripsi, Tesis, dan Disertasi (1st ed.; A. Cristian, ed.). Yogyakarta: ANDI.

Susanti, N., Rahmayanti, R., Padmakusumah, R. R., \& Susanto, R. (2019). Factors affecting students' financial literation: A study on Widyatama University, Indonesia. Universal Journal of Educational Research, 7(5), 7-14. https://doi.org/10.13189/ujer.2019.071502

Syuliswati, A., \& Malang, P. N. (2019). Faktor-faktor yang mempengaruhi literasi keuangan mahasiswa jurusan akuntansi politeknik negeri malang. Prosiding SNAMK (Seminar Nasional Akuntansi Manajemen Dan Keuangan), 1(1).

Shalahuddinta, A., \& Susanti. (2014). Pengaruh Pendidikan Keuangan di Keluarga, Pengalaman Bekerja, dan Pembelajaran. Jurnal Pendidikan Akuntansi, 2(2), 1-10. Retrieved from https://jurnalmahasiswa.unesa.ac.id/index.php/jpak/article/view/9134

Ulfatun, T. (2016). Analisis Tingkat Literasi Keuangan Mahasiswa Fakultas Ekonomi Universitas Negeri Yogyakarta Tahun Angkatan 2012-2014. Pelita - Jurnal Penelitian Mahasiswa UNY, 11(2), 1-13. https://doi.org/https://journal.uny.ac.id/index.php/pelita

Yadnyana, I. K. (2018). Effects of Learning Quality, Social-Economic Status and Entrepreneurship Spirit on Financial Literacy of Students of Udayana. International Journal of Management and Commerce Innovations, 6(1), 72-77. https://doi.org/www.researchpublish.com

Wardani, E. W., Susilaningsih, \& Sangka, K. B. (2017). Faktor-Faktor yang Mempegaruhi Literasi Keuangan Mahasiswa Program Studi Pendidikan Akuntansi Fakultas Keguruan dan Ilmu Pendidikan Universitas Sebelas Maret. Jurnal "Tata Arta" UNS, 3(3), 80-93. 